\title{
Riset aksi partisipatif: Festival kebudayaan menghadapi intoleransi
}

\author{
Justito Adiprasetio ${ }^{1}$, Andika Vinianto Adiputra ${ }^{2}$ \\ ${ }^{1,2}$ Universitas Padjadjaran, Bandung, Indonesia
}

\begin{abstract}
ABSTRAK
Indonesia saat ini mengalami ancaman gelombang intoleransi yang memprihatinkan, berbagai fakta lapangan seperti penyerangan tokoh agama, rumah ibadah dan berbagai persekusi, serta studi-studi pendahulu menunjukkan permasalahan tersebut. Mengacu pada strategi yang diterapkan oleh UNESCO, terdapat beberapa hal yang dapat dilakukan untuk melawan gejala intoleransi yaitu dengan meningkatkan pengetahuan melalui pendidikan berbasis multikulturalitas dan pluralisme, peningkatan kesadaran individu dan solusi lokal lain yang bersifat akar rumput. Ketiganya dapat dirangkum melalui pengadaan kegiatan kebudayaan: festival. Festival di berbagai negara, kerapkali digunakan untuk menanamkan nilai-nilai keberagaman: multikulturalisme dan pluralisme. Studi ini dengan menggunakan metodologi riset aksi partisipatif dan dikombinasikan dengan etnografi berupaya untuk menyusun pilot-project festival yang mempromosikan semangat toleransi. Partisipan dari penelitian ini adalah 600 mahasiswa yang berasal dari 5 program studi di Fakultas Ilmu Komunikasi (Fikom), Universitas Padjadjaran, yang sebelumnya telah mendapatkan mata kuliah Komunikasi Lintas Budaya. Hasil penelitian menunjukkan bahwa festival kebudayaan adalah sarana yang tepat untuk mengembangkan visi multikulturalisme dan pluralisme sekaligus menggeser narasi-narasi esensialisme kebudayaan. Riset ini membuktikan bahwa festival secara spesifik dapat ditargetkan untuk menyebarkan nilai-nilai toleransi, apabila memang partisipannya dilibatkan secara utuh dan berkesinambungan. Keberhasilan penyelenggaraan festival kebudayaan di Fikom menjadi jawaban dan pengejawantahan bahwa sangat mungkin festival-festival sejenis dapat diselenggarakan di tempat lain dengan tujuan yang sama, dan terutama menyasar generasi muda.
\end{abstract}

Kata-kata Kunci:Budaya; festival; multikulturalisme; pluralisme; toleransi

\section{Participative action research: Cultural festival opposing intolerance}

\section{ABSTRACT}

Indonesia is currently facing the challenge of an alarming wave of intolerance, various field facts such as attacks on religious leaders, attacks on houses of worship, and various persecutions, as well as previous studies magnifying the issue. In Reference to the strategy adopted by UNESCO, the implementation of several approaches to fight intolerance, such as increasing knowledge through multiculturality-based education and pluralism, raising individual awareness, and local solutions related to grassroots movements. All those outlined through the provision of cultivation activities: festivals. Festivals in various countries are often used to instill values of diversity: multiculturalism and pluralism. This study uses participatory research experiments combined with ethnography, which supports the development of festival pilot-project that promote the spirit of tolerance. The participants of this study are 600 students from 5 study programs at the Faculty of Communication Sciences (Fikom), Universitas Padjadjaran, who had previously received a Cross-Cultural Communication subject course. The results show that the cultural festival is the right medium to develop a vision of multiculturalism and pluralism while shifting the narratives of cultural essentialism. This research proves that cultural festivals can be specifically targeted in spreading the values of tolerance if all the participants involved with commitment and persistence. The success of the cultural festival held at Fikom is the answer and enactment of duplication of similar festivals held in other places with the same purpose, especially targeting the younger generation would be plausible.

Keywords: Culture; festival; multiculturalism; pluralism; tolerance

Korespondensi: Justito Adiprasetio. Universitas Padjadjaran. Jl. Raya Bandung Sumedang KM.21, Hegarmanah, Kec. Jatinangor, Kabupaten Sumedang, Jawa Barat 45363. Email: justito.adiprasetio@unpad. ac.id 


\section{PENDAHULUAN}

Terdapat berbagai proyeksi yang menunjukkan bahwa Indonesia sedang mengalami peningkatan derajat intoleransi. Hal tersebut dapat dilihat dalam berbagai kasus pada awal tahun 2018 di mana terdapat beberapa tokoh agama yang mengalami penganiayaan, yaitu K.H. Umar Basri (27 Januari 2018, Kab. Bandung), Ustadz Prawoto (1 Februari 2018, Bandung) dan Romo Prier (11 Februari 2018, Sleman) (Gerintya, 2018). Tidak hanya penyerangan ulama agama, publik juga dapat mendapatkan berbagai potret penyerangan terhadap rumah ibadah seperti penyerangan Pura di Lumajang, perusakan masjid di Tuban, Penyerangan Gereja Sata Lidwina di Sleman, persekusi terhadap Biksu di Tangerang dan acaman bom di kelenteng Kwan Tee Koen (Rochmanuddin, 2018). Fakta-fakta lapangan tersebut juga diperkuat dengan data makro yang dipaparkan oleh berbagai institusi riset, Setara Institute menyebutkan terdapat sepuluh kota dengan skor toleransi terendah. Pada posisi pertama kota dengan skor toleransi terendah ditempati oleh DKI Jakarta, disusul oleh Banda Aceh, Bogor, Cilegon, Depok, Yogyakarta, Banjarmasin, Makassar, Padang dan Mataram (Setara, 2018). Suatu hal yang ironis, posisi pertama ditempati oleh DKI Jakarta yang merupakan Ibu Kota Indonesia. DKI mengalami penurunan peringkat dari 65 menjadi peringkat 94 (skor terendah), hal yang mencengangkan mengingat DKI Jakarta sebagai Ibu Kota seharusnya dapat menjadi potret dari kondisi keberagaman sekaligus toleran di dalam keberagaman tersebut. Data yang dikeluarkan oleh Setara Institute juga diperkuat oleh Kemdikbud yang menyatakan bahwa toleransi antar umat beragama di Indonesia terbilang rendah (Hadi, 2017). Berdasarkan proyeksi tersebut, diperlukan suatu penanganan dan intervensi untuk mencegah penyebaran dan efek diskursif dari fenomena intoleransi ini.

Beberapa hal yang dapat dilakukan untuk melawan gejala intoleransi tersebut adalah dengan meningkatkan pengetahuan melalui pendidikan berbasis multikulturalisme dan pluralisme, peningkatan kesadaran individu dan solusi lokal lain yang bersifat akar rumput (UNESCO, 2009). Namun tentu saja hal tersebut juga harus ditopang oleh kerangka dan penegakan hukum yang kuat dan jelas. Salah satu metode untuk menanamkan ideologi toleransi adalah melalui praktik-praktik kebudayaan yang memiliki potensi besar menjadi sarana dialog antar-agama dan bahkan antar-etnis, seperti Festival. King (2016) mengelaborasi bagaimana musik dan festival dapat dan telah mempromosikan kedamaian antar umat beragama. Festival yang diselenggarakan di Maroko, Morocco the Festival of World Sacred Music berhasil membawa peserta trans-nasional dengan latar agama berbeda: Kristen, Muslim dan sekularis berpartisipasi menikmati musik. Hal yang sama juga terjadi di Lebanon di mana, penampilan musik Arab klasik, pembacaan naskah klasik, kitab suci dan puisi membuat musisi dan ulama Muslim dan Kristen berada di satu panggung dan acara yang sama berbendang bersama. Shinde (2015) mengeksplorasi bahwa festival dan turisme berhasil meningkatkan relasi antar agama dan toleransi antar agama di India.

Selama ini festival yang diselenggarakan di Indonesia, kebanyakan sangat menonjolkan lokalitas, seperti Festival Karapan Sapi di Madura, Karnaval batik dan Festival Sekaten di Solo, Festival Danau Toba, Festival Lebaran Betawi, Dieng Culture Festival, Festival Danau Sentani di Jayapura dan Festival Tabuik di Sumatera Barat. Hal ini sesuai dengan elaborasi Fine (2012) yang mendeskripsikan festival sebagai "microgathering yang terfokus" dan "pola arketip dari komunitas yang ringan". Komunitas kecil/kelompok kecil adalah blok bangunan dasar masyarakat dan memainkan peran penting dalam mengatur kehidupan sosial dan pengembangan budaya lokal. Pada konteks tersebutkebutuhan atas penyelenggaraan festival menjadi mendesak dilakukan. Hanya sedikit festival di Indonesia yang diselenggarakan dengan tujuan menonjolkan keragaman budaya atau memersatukan berbagai elemen lokalitas dan globalitas, salah satu dari yang sedikit adalah Festival Toleransi: Indonesia Rumah Bersama.

Festival sendiri dapat dimengerti sebagai sebagai "an occasional public" - atau publik yang muncul sesekali, di mana aksi lokal dan kekuatan sosial yang lebih besar berkumpul untuk periode yang terbatas untuk terlibat dalam praktik-praktik kebudayaan (Wynn, 2015). Penjelasan Wynn (2015) mengarahkan bahwa festival tidak hanya dapat diaplikasikan dalam konteks lokalitas saja, namun juga dalam 
publik yang lebih besar dan fragmen-fragmen yang lebih beragam. Penelitian ini mencoba mengintervensi langsung dengan menggunakan metode Riset Aksi Partisipatif - Participative Action Research (PAR) untuk melakukan eksperimen dalam membangun festival kebudayaan yang tepat untuk diselenggarakan dalam konteks Indonesia yang multi-kultural dan dengan latar etnisitas dan keagamaan yang berbeda-beda. PAR juga akan dikombinasikan dengan metode etnografi partisipatif, untuk membaca persepsi dan respon terhadap festival kebudayaan yang diselenggarakan.

Festival kebudayaan sebagai jantung sekaligus objek eksperimen dalam studi ini diselenggarakan dengan tajuk Festival Budaya: Celebration of World Heritage (Perayaan atas Warisan Dunia) yang melibatkan 600 Mahasiswa Fakultas Ilmu Komunikasi Universitas Padjadjaran. Riset menunjukkan bahwa generasi muda di berbagai belahan dunia saat ini memiliki kecenderungan lebih toleran bila dibandingkan dengan generasi sebelumnya, seperti yang terjadi di Inggris (Janmaat \& Keating, 2017) dan Malaysia (Nizah, 2017). Walaupun masih terdapat jejakjejak sifat dan sikap diskriminatif yang terbawa akibat tradisi, namun generasi muda dengan visi kosmopolitannya serta toleransi yang dibawa dari lingkungannya, potensial menjadi katalis perubahan dalam lingkup kultural yang lebih besar. Hal tersebut yang menjadi alasan, mengapa studi ini mengambil generasi muda yang diwakili oleh mahasiswa sebagai partisipannya.

Sebelumnya, mahasiswa yang menjadi partisipan dalam festival kebudayaan telah diberi bekal terlebih dahulu dalam kerangka kurikulum yang sama di dalam mata kuliah Komunikasi Lintas Budaya. Tidak hanya memeragakan kebudayaan lokal yang terfragmen: Minangkabau, Bali, Aceh, Sunda, Jawa, Manado, Palembang, Batak, Dayak, juga mencoba mengeksplorasi kebudayaan Jepang, Jerman, Korea Selatan, Yunani, Belanda, Mesir, Turi, Perancis, Amerika, Australia, Kanada, Inggris, Arab Saudi, Norwegia, Thailand, Tiongkok, India, Italia, Brazil dan Rusia. Diharapkan festival kebudayaan ini dapat menjadi pilot-project untuk festival-festival kebudayaan yang akan diselenggarakan dengan tujuan memerkenalkan keragaman budaya dengan berbagai latar etnisitas dan agama di
Indonesia.

Tak sedikit studi tentang festival yang telah dilakukan, tak terkecuali studi-studi kontemporer yang menitikberatkan pada bagaimana festival mempengaruhi kehidupan sosial dan kebudayaan. Festival dapat meningkatkan kebanggaan dan partisipasi warga sipil (Wood \& Thomas, 2006), dan bahkan mendorong pembangunan agensi ekonomi lokal apabila diintegrasikan dengan turisme (Thomas \& Wood, 2003). Festival dengan partisipasi dan keterikatan masyarakat yang baik akan memperkuat image suatu wilayah karena informasi akan tersebar dari mulut-ke-mulut secara positif(Lee et al., 2014). Sosiolog dalam beberapa tahun terakhir telah menerapkan pendekatan sosiologis lokal untuk studi-studi terkait festival (lihat Delgado, 2016; Wynn, 2015). Berbagai unsur ketidakpastian, multivokalitas dan karnaval pada suatu festival memberikan peluang bagi individu dan kelompok yang berbeda untuk mempromosikan berbagai agenda yang mereka miliki dan berada di bawah payung kebersamaan dan toleransi (Yeoh, 2001). Festival dapat diterjemahkan sebagai demokratisasi ruang publik, yang mana aktualisasinya adalah mendorong narasinarasi budaya terpinggir untuk dapat menjadi dan ambil bagian dalam praktik kebudayaan. Mekanisme representasi kebudayaan tersebut

Festival menjadi arena wacana yang memungkinkan masyarakat untuk mengekspresikan pandangan mereka terkait isu-isu budaya, sosial dan politik yang lebih luas. Hal yang membuat, walaupun festival akan selalu merupakan tegangan antara dua polar yang berbeda: polar yang menganjurkan perubahan dan polar yang ingin melestarikan budaya "tradisional" atau "lokal" dalam menghadapi modernisasi dan globalisasi, namun akan selalu ada negosiasi dan hibridasi di antara kedua polar tersebut, yang dalam kondisi ideal akan menghasilkan harmonisasi (Crespi-Vallbona \& Richards, 2007).

Seperti yang telah disebutkan, studi ini menggunakan pendekatan Riset Aksi Partisipatif-Participative Action Research (PAR), dengan deskripsi sebuah proses partisipatif yang berkaitan dengan pengembangan pengetahuan praktis dalam mengejar tujuan-tujuan manusia yang berarti. PAR berusaha untuk menyatukan tindakan dan refleksi, teori dan praktik, dalam partisipasinya 
Tabel 1 Tujuh ciri Khas Participative Action Research

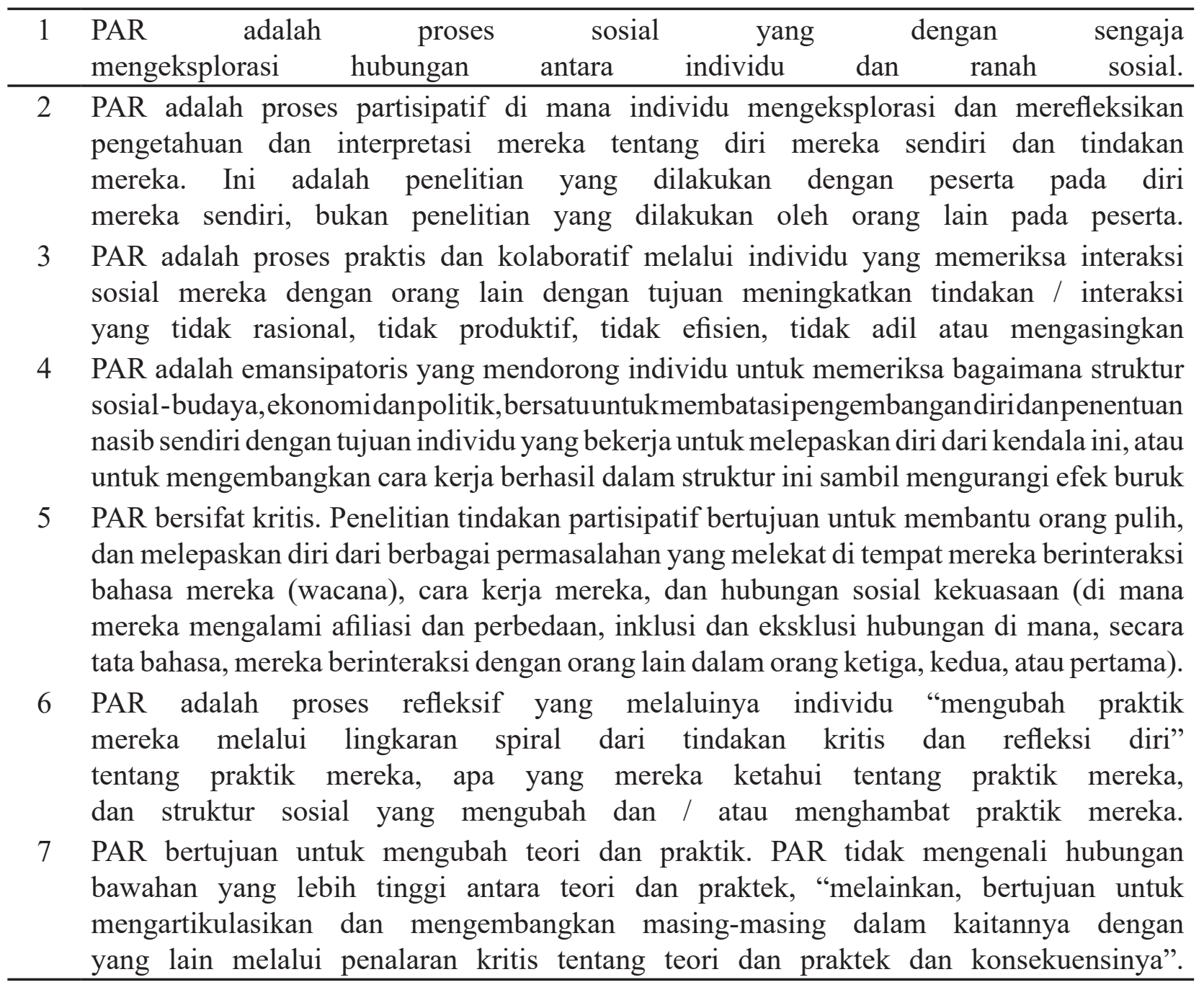

Sumber: Kemmis \& McTaggart, 2005

dengan orang lain, dalam mengejar solusi praktis untuk isu-isu yang mendesak, dan lebih umum pada perkembangan individu maupun komunitas (Kemmis, 2006). PAR memiliki target untuk berkontribusi pada upaya membangun pengetahuan dan membawa perubahan atau transformasi sosial (Kemmis \& McTaggart, 2005; Lykes, Hershberg, \& Brabeck, 2011; MacDonald, 2012 \& Stoudt, 2009)

Kemmis dan McTaggart (2005) mendeskripsikan tujuh ciri khas PAR dalam tabel 1.

Berdasarkan pendekatan PAR yang telah dijelaskan, peneliti berupaya menyusun metodologi penelitian yang digunakan tidak hanya sebagai pisau analisis namun juga sebagai penunjuk jalan selama proses penelitian ini dilaksanakan.

\section{METODE PENELITIAN}

Pada tahapan pertama, peneliti akan melakukan serangkaian wawancara kualitatif yang tidak terstruktur dan melakukan diskusi group, dengan tujuan utama menghasilkan hipotesis awal. Sumber data lain, seperti jurnal, dokumen formal, laporan surat kabar, laporan suratkabar, literatur dari bidang substantif atau bidang lainnya, dan pengalaman pribadi dapat ditambahkan ke kumpulan data dalam bentuk memo. Memo tersebut kemudian akan kembali didiskusikan kepada partisipan yang menjadi penggerak kegiatan.

Pada tahapan kedua meliputi: pengidentifikasian kebutuhan vital, penanaman aspek toleransi dan ketahanan akan etnosentrisme, pengidentifikasian tujuan dan detil aktivitas, pengidentifikasian metode 
komunikasi yang tepat. Perbedaan latar belakang dan karakter dari partisipan akan coba diidentifikasi dalam tahapan kedua penelitian ini, dengan tujuan akhir menemukan model festival kebudayaan yang tepat.

Pada tahapan ketiga Seperti yang dijabarkan oleh Kemmis \& McTaggart (2005) dalam Participatory Action Research, bahwa ide fundamental dari action research dan action learning adalah membawa partisipan bersama, belajar satu sama lain dari masing-masing pengalaman yang didapat. Tahapan ketiga ini akan dilakukan melalui pembelajaran bersama dengan partisipan, melalui metode trial and error, percobaanberkali-kalidengan serangkaian evaluasi untuk mendapatkan metode yang tepat dalam pengembangan pembuatan model festival kebudayaan. Harapannya output yang didapatkan akan sesuai dengan self-efficacy, di mana partisipan akan dapat menguji diri mereka sendiri dalam hal kesesuaiannya dengan model festival kebudayaan yang akan dan sedang diterapkan, hal tersebut memiliki tujuan agar penggunaan model festival kebudayaan akan sesuai.

Pada tahap keempat meliputi pelaksanaan festival kebudayaan secara partisipatif Sebagai bagian akhir dari penelitian. Penelitian ini akan menggunakan model yang dibuat oleh Kemis dan McTaggar dalam Participatory Action Research. Pada gambar 1.

Output dari action research akan didapatkan melalui dua lapis refleksi, sehingga tujuan akhir daripenelitian ini dapat tercapai. Metode PAR kemudian akan dikombinasikan dengan pendekatan etnografi. Etnografi digunakan untuk membaca struktur ideologi dan pengalaman subjek-subjek yang berpartisipasi dalam festival kebudayaan.

Teknik analisis secara keseluruhan yang digunakan dalam penelitian ini adalah teknik analisis kualitatif. Secara umum penelitian kualitatif adalah proses penelitian untuk memahami fenomena, didasarkan pada tradisi penelitian dengan metode yang khas, dengan objek masalah masyarakat. Peneliti mengumpulkan data yang berserak, merangkaikannya sehingga membangun suatu gambaran yang kompleks dan holistik, menganalisis kata-kata, melaporkan pandangan informan secara terperinci yang keseluruhan langkah penelitiannya dilakukan dalam setting alamiah (Moleong, 2006). Studi ini dalam

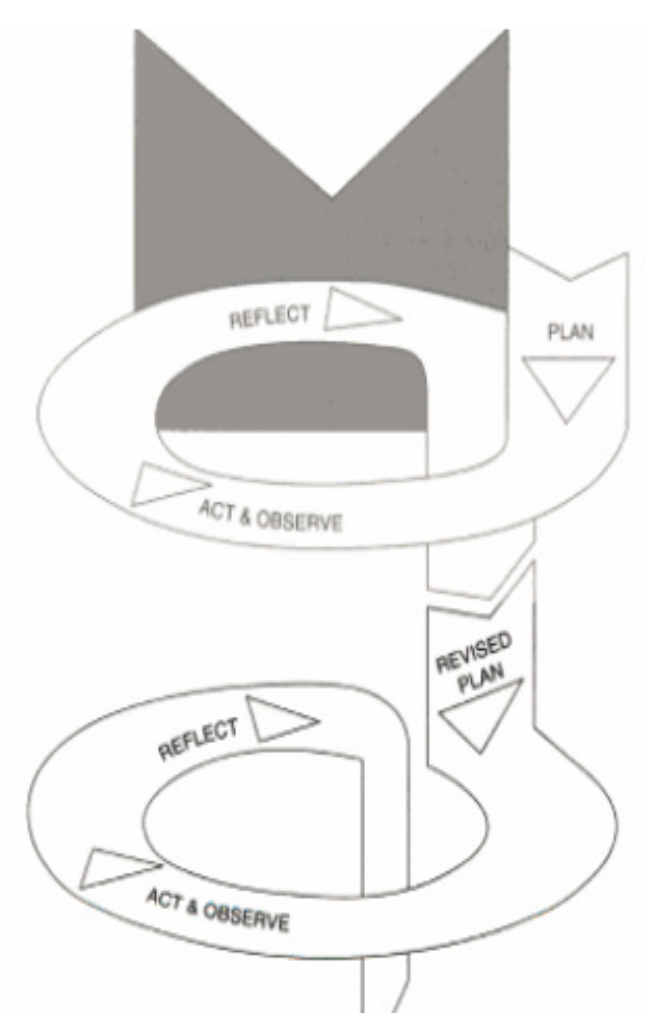

Sumber: Denzin \& Lincoln, 2005

Gambar 1. Model Participatory Action Research

penyampaiannya akan menggunakan penekanan naratif, yang membuat proses dari riset kualitatif dapat tergambarkan dengan kompleks.

\section{HASIL DAN PEMBAHASAN}

Proses penyelenggaraan festival kebudayaan mulai dipersiapkan sejak hari pertama perkuliahan Komunikasi Lintas Budaya. Mata kuliah Komunikasi Lintas Budaya diselenggarakan secara umum di semua Program Studi yang terdapat di Fakultas Ilmu Komunikasi Universitas Padjadjaran: Hubungan Masyarakat, Manajemen Komunikasi, Jurnalistik dan Ilmu Perpustakaan. Secara deskriptif mata kuliah ini berisi pembelajaran terkait teori, praktik beserta konsekuensi-konsekuensi dalam menghadapi berbagai proses komunikasi dalam lingkup kebudayaan yang berbeda, baik dalam kebudayaan dalam arti suku bangsa maupun kebiasaan sehari-hari (Hartoyo, 2016). Pada proses-nya mata kuliah ini juga mempelajari strategi dalam memperoleh dan menyiarkan informasi secara lintas budaya. Tujuan normatif perkuliahan ini adalah mahasiswa diharapkan dapat memahami konsep toleransi antar budaya, 
memiliki kemampuan adaptasi, empati serta pikiran terbuka untuk menerima perbedaan dan memiliki kemampuan komunikasi antar-pribadi yang berguna dalam menjalin hubungan dengan siapapun (Hartoyo, 2016).

Terdapat beberapa materi yang menjadi fondasi dalam pengenalan komunikasi lintas budaya, yaitu mahasiswa dipastikan dapat memahami definisi dan karakteristik budaya, dimensi-dimensi budaya, asumsi, proses dan elemen komunikasi lintas budaya dan berbagai model komunikasi lintas budaya (Gudykunst \& Kim, 1997; Samovar, Porter, \& McDaniel, 2007). Materi tersebut dilanjutkan dengan peran sosial Bahasa dalam praktik kebudayaan dan cermin dari nilai budaya (Liliweri, 2007). Jumlah pertemuan dalam proses pembelakan materi ini. Materi tersebut diberikan pada paruh pertama dari mata kuliah komunikasi Lintas Budaya, yang diselenggarakan tujuh pertemuan.

Materi pada paruh kedua, yang juga terdiri dari tujuh pertemuan berisi pada kaitannya tentang identitas kebudayaan: identitas ras, etnik, gender, nasionalisme, agama; dimensidimensi konflik: Pengertian, sebab, strategi untuk menghadapinya; budaya populer dan perkembangannya di dunia dan iIndonesia, globalisasi dan kaitannya dengan kekuasaan, industri kreatif dan imperialisme budaya. Bagian ini akan ditutup dengan materi terkait ragam pendekatan etis komunikasi antar budaya, juga cara beradaptasi dan penempatan empati (Samovar dkk, 2007).

Setelah perkuliahan selesai, dengan bekal yang cukup mahasiswa-mahasiswi mulai mempersiapkan festival kebudayaan. Diskusi dengan intervensi dari pengajar mata kuliah Komunikasi Lintas Budaya menyimpulkan beberapa hal yang harus dibahas sejak awal yaitu: 1.) Penentuan dan kesesuaian tema kelompok dengan tema festival. 2.) Pembuatan konsep program (mencakup latar belakang, tujuan, sasaran, strategi). 3.) Rangkaian protokol (meliputi time, space, tempo, decorating/sites, catering, safety, amenities, life entertainment, event coordinator), dengan catatan durasi penampilan setiap kelompok dibatasi maksimal 15 menit yang diikuti sesi tanya jawab 10 menit. Setiap penampil juga diberikan tugas untuk membuat makalah kelompok sebagai pertanggungjawaban dari presentasi yang mereka tampilkan dan terbagi dalam dua bagian yaitu budaya dan tantangan globalisasi, dan budaya dalam konteks masyarakat global. Terdapat 24 kelompok yang terdiri dari masingmasing Program Studi yang ada di Fikom Unpad. Setiap kelompok akan memperoleh kesempatan mengambil undian kelompok budaya dan ritual budaya yang harus dipresentasikan, dengan komposisi budaya Nasional dan Internasional 2:3. Terdapat 9 kelompok yang akan mempresentasikan 9 budaya yang nasional dan 15 kelompok sisanya akan mempresentasikan 15 budaya yang didapatkan dari mancanegara.

Diskusi yang diselenggarakan melalui dua kali rapat dan dilanjutkan dengan diskusi intens di grup WhatsApp didapatkan simpulan bahwa festival kebudayaan akan menampilkan representasi dari kebudayaan lokal yaitu: Minangkabau, Bali, Aceh, Sunda, Jawa, Manado, Palembang, Batak, Dayak, juga mencoba mengeksplorasi kebudayaan internasional Jepang, Jerman, Korea Selatan, Yunani, Belanda, Mesir, Turi, Perancis, Amerika, Australia, Kanada, Inggris, Arab Saudi, Norwegia, Thailand, Tiongkok, India, Italia, Brazil dan Rusia. Terdapat konsekuensi yang diambil dengan pembagian atas dua konstruk kebudayaan, yang pertama adalah penonjolan fragmen Indonesia tentu akan melibatkan berbagai aspek etnisitas yang detail namun di saat yang sama pengambilan sampel kebudayaan Internasional tidak berdasarkan etnisitas namun berdasarkan kategori negara, tentu saja yang terjadi adalah simplifikasi terhadap aspek-aspek kebudayaan negara. Kedua, adalah bagaimana mengemas berbagai nilai-nilai budaya dan praktik kebudayaan tanpa melepaskan diri dari aspek substansial-nya, namun tetap harus dapat disampaikan secara populer, dengan kata lain ia harus menjadi ajang performatif yang universal. Kedua hal ini yang kemudian mengarahkan pada kompromi bahwa performativitas dari representasi negaranegara lain, tidak akan sedetail penampilan dari kebudayaan lokal yang lebih menonjolkan detail-detail dari praktik kebudayaan berdasarkan etnisitas. Namun, kompromi tersebut dilaksanakan sebisa mungkin, tidak melampaui tujuan awal, dan diusahakan untuk menghindari masalah-masalah representatif seperti stereotip kebudayaan dan generalisasi atas nilai-nilai budaya yang berlebihan.

Setiap kelompok memilih seorang Duta Budaya (Culture Ambassador). Duta Budaya memiliki peran sentral dalam kelompok. Ia 
akan menjadi juru bicara dalam presentasi budaya sekaligus menjadi perwakilan (representasi) budaya yang ditampilkan. Setiap kelompok harus memilih seorang Ketua dan Wakil Kelompok. Ketua dan Wakil Kelompok tidak merangkap sebagai Duta Budaya. Ketua dan wakil kelompok akan melaksanakan fungsi koordinasi dengan Panitia pelaksana, Ketua Kelas dan bersama-sama dengan ketua dan wakil kelompok lain. Panitia Pelaksana adalah tim yang ditunjuk dan dikoordinasikan oleh Manajer Kemahasiswaan dan Hubungan Alumni Fakultas Ilmu Komunikasi Universitas Padjadjaran. Panitia Pelaksana ini akan berperan sebagai kordinator acara yang lingkup tugasnya mencakup: 1.) Mengoordinir pelaksanaan acara dan berkoordinasi dengan dosen PIC festival kebudayaan (Andika Vinianto dan Justito Adiprasetio - penulis). 2.) Mengurus perizinan pemakaian lokasi Festival dan melakukan koordinasi dengan ketua kelompok peserta festival kebudayaan. 3.) Mengatur dan memastikan tata ruang dan letak stand kelompok-kelompok peserta festival, tata suara dan keperluan logistik lainnya tersedia di lokasi. 4.) Berkoordinasi dengan dosen PIC Festival kebudayaan dan petugas-petugas pendukung (petugas logistik kampus, petugas kebersihan, satpam, dll.). 5.) Mengatur urutan giliran presentasi dan memastikan seluruh rangkaian Festival akan dimulai. 6.) Kegiatan Festival akan meliputi kegiatan sebagai berikut: pawai atau defile perwakilan kelompok-kelompok peserta Festival, Peninjauan stand Festival oleh tim pengajar dan peneliti untuk penjelasan komprehensif budaya di stand peserta, presentasi/pertunjukan budaya di panggung utama, dan panitia dapat bekerja sama dengan pihak-pihak lain yang relevan untuk keperluan sponsor atau dapat pula mengadakan bazaar dengan menjaring pengusaha UMKM yang bergerak dalam ranah budaya yang ditampilkan dalam festival. Kordinator acara dapat pula membuat publikasi sederhana agar civitas academica Fakultas Ilmu Komunikasi dan Universitas Padjadjaran dari seluruh jenjang dan lapisan serta masyarakat Jatinangor dapat turut menikmati dan berpartisipasi dalam Festival.

Dalam diskusi yang ada, kemudian disimpulkan juga bahwa Festival Kebudayaan akan melibatkan siswa dan siswi dari SMAN 1 Jatinangor sebagai representasi dari warga yang tinggal di sekitar Jatinangor. Mereka yang akan dilibatkan adalah anak-anak SMAN 1 Jatinangor yang memiliki latar belakang seni: tari, musik, seni rupa, sedangkan siswasiswi SMAN 1 Jatinangor yang lain, akan diajak berpartisipasi sebagai tamu untuk dapat turut serta menyaksikan festival yang diselenggarakan.

Proses penjajakan tersebut dimulai dengan permintaan izin kepada SMAN 1 Jatinangor. Setelah izin didapatkan dari pihak pengampu kebijakan sekolah, proses dilanjutkan dengan diskusi dan negosiasi terkait apa saja yang akan ditampilkan oleh SMAN 1 Jatinangor di Festival kebudayaan. Untuk mempersiapkan penampilan dalam Festiva Kebudayaan, diperlukan pengetahuan atas aspek-aspek konseptual dari kebudayaan, relasi antar budaya, dan konsep-konsep kebudayaan yang lain, untuk itu diperlukan pemberian materi tentang kebudayaan yang lebih dalam dan tentu saja memiliki distingsi dengan materimateri kebudayaan dan multikulturalisme yang diajarkan secara umum di jenjang sekolah menengah.

Pemberian materi dan pengarahan diskusi terkait kebudayaan dilakukan tidak oleh tim peneliti, namun oleh mahasiswa dan mahasiswi yang sudah menjalankan perkuliahan Komunikasi Lintas Budaya sebelumnya. Hal ini ditujukan untuk menguji kemampuan pemahaman sekaligus kemampuan pentransmisian pemahaman tersebut ke level yang berbeda. Peran peneliti hanyalah sebagai moderator dan penjaga agar materi yang disampaikan tidak melenceng dan dapat membumi, sesuai dengan lingkup dan medan wacana di mana siswa-siswi SMAN 1 Jatinangor beraktivitas. Terdapat 21 siswa-siswi, 13 perempuan dan 8 laki-laki yang berpartisipasi dalam penyampaian materi dan diskusi tersebut

Proses pemberian materi tidak dilakukan dengan satu arah, namun melalui diskusi, dapat dilihat pada gambar 2. Mahasiswa memberikan penjelasan terlebih dahulu tentang bagaimana kebudayaan dalam berbagai dimensi ilmu pengetahuan: antropologi, sosiologi dan komunikasi. Relasi antar kebudayaan, dan bagaimana transaksi juga transmisi kebudayaan dalam historisitas kebudayaan nasional, maupun internasional. Dilanjutkan dengan pemaparan tentang masalah-masalah yang riskan ditemui dalam praktik kebudayaan sehari-hari, seperti: stereotip, ultra-nasionalisme dan rasisme. 


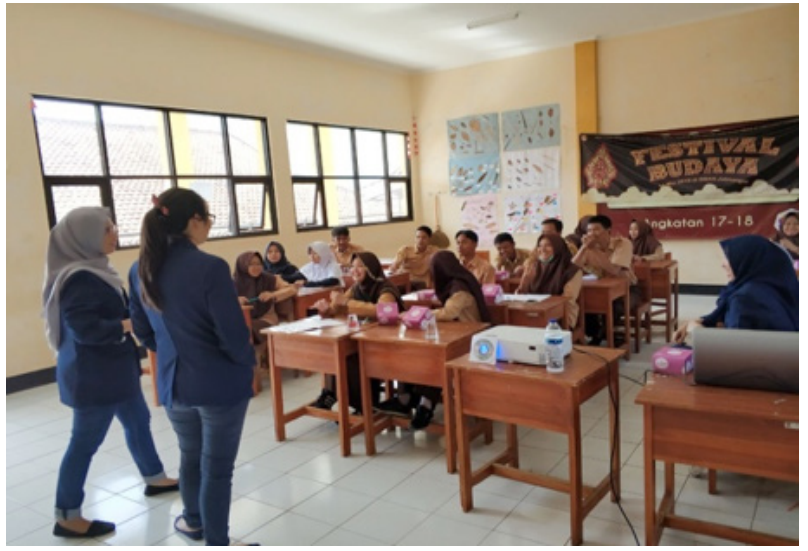

Sumber: Hasil Penelitian, 2019

Gambar 2 Proses Diskusi di SMAN 1 Jatinangor

Berdasarkan artikel Teaching tolerance? Associational Diversity and Tolerance Formation (2015), diperlukan engagement yang berkelanjutan dan konsisten untuk menumbuhkan toleransi. Engagementdapat melalui berbagai kegiatan dan aktivitas yang memang melibatkan partisipasi dari berbagai unsur kebudayaan. Peserta nampak dapat mengikuti dan memahami diskusi yang ada, simpulan ini didapatkan dari respon-respon yang dilontarkan oleh peserta ketika diskusi dilakukan.

"Ternyata kebudayaan gak sesederhana itu, dan memang tidak baik kalau kita membuat stereotip untuk orang yang berasal dari kebudayaan yang berbeda"

HJ - Siswa X IPA 1

"Budaya Sunda sama, maksudnya saya, setara dengan budaya lain, seperti Jawa, Madura, Bali, tapi saya heran kenapa banyak orang yang menganggap kebudayaannya lebih baik dibandingkan dengan budaya lain.

SA - Siswi XI IPA 6

"Indonesia terdiri dari dari berbagai macam kebudayaan, juga agama. Memang sudah semestinya kita saling menghargai juga menghormati antar (mereka yang berasal dari *catatan penulis) kebudayaan yang berbeda, dan antar agama"

ASM - Siswi X IPA 3

Sebagian anak-anak SMAN 1 Jatinangor yang menjadi partisipan bahkan menganggap bahwa pandangan tentang kebudayaan yang diajarkan selama ini di sekolah masih terbilang kurang, sehingga diperlukan materi-materi kebudayaan yang lebih jauh, dan materi pengajaran agama yang lebih progresif, dalam arti dapat memberikan pemahaman yang lebih jauh tentang bagaimana etika menghadapi keragaman agama di Indonesia.

"Saya rasa, materi pelajaran tentang toleransi dan keberagaman di sekolah tidak cukup banyak.Semestinya materi semacam ini (multikulturalisme dan toleransi antaragama) diajarkan di mata pelajaran-mata pelajaran. Jadi kami-kami bisa paham lebih banyak" (WL - XI IPA 7).

"Iya, sepertinya materi semacam ini (multikulturalisme dan toleransi antaragama) di pelajaran sekolah tidak banyak. Sekolah hanya memberikan pelajaran yang itu-itu saja. [...] Materi itu malah nggak sengaja didapetin dari pelajaran tambahan seperti kesenian, jadi kita tahu bahwa kebudayaan itu beragam dan bisa kita pelajari"

NNA - XI IPA 6

Setelah proses diskusi intens yang dilakukan, siswa SMAN 1 Jatinangor diberikan waktu untuk mendiskusikan kesenian dan kebudayaan apa saja yang akan ditampilkan. Diskusi tersebut tidak berlangsung pada satu pertemuan atau satu momen saja, karena berkait dengan perhitungan modalitas yang mereka miliki: kemampuan, sarana dan prasarana serta persiapan apa saja yang harus dilakukan untuk mementaskan tersebut. Proses diskusi kemudian menghasilkan simpulan bahwa mereka akan mementasikan suatu pertunjukan yang merupakan fusi dari budaya Sunda, Manado dan Batak. Setelah hal tersebut disepakati, kemudian dilanjutkan dengan proses latihan dan persiapan.

Proses latihan pertunjukan yang terdiri dari seni tari dan musik dilakukan selama $2 \mathrm{x}$ seminggu dalam kurun waktu 3 minggu, dapat dilihat pada gambar 3 dan 4. Sedangkan siswa-siswi yang memfokuskan diri pada seni rupa mempersiapkan ornamen stand yang akan mereka tempati pada saat festival diselenggarakan.

Bersamaan dengan persiapan siswa-siswi SMAN 1 Jatinangor, peserta dari Fikom Unpad 


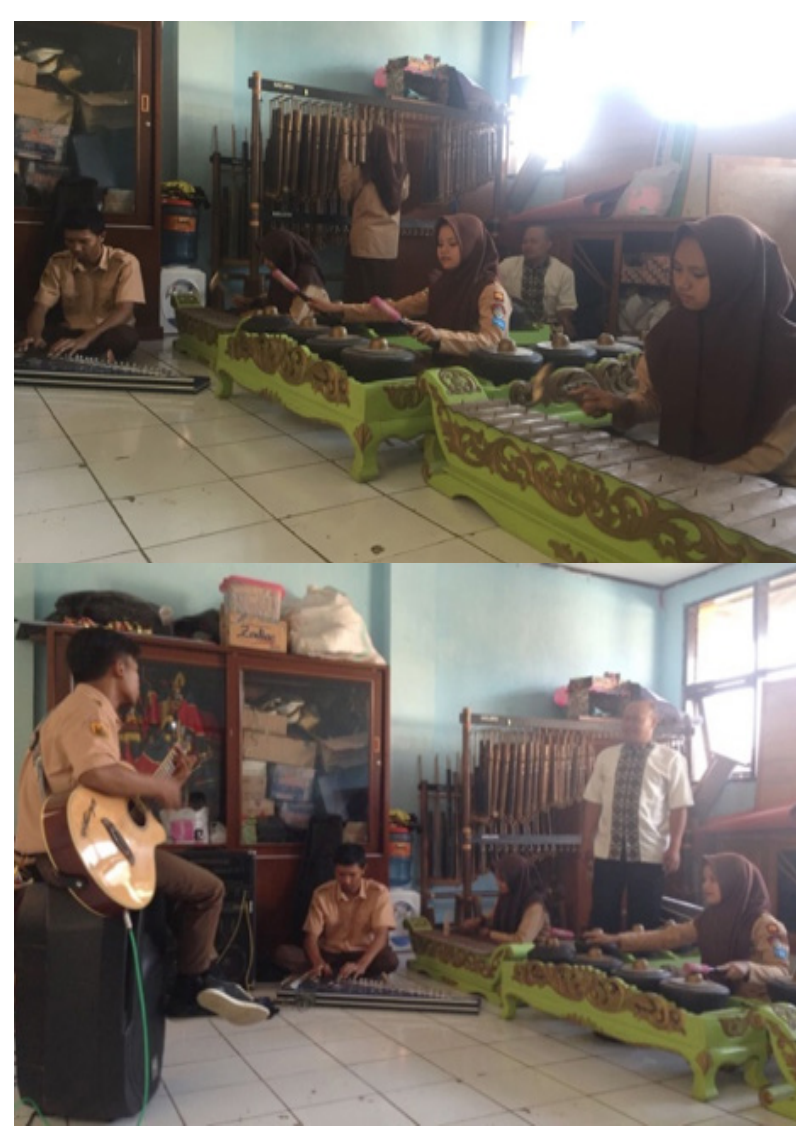

Sumber: Hasil Penelitian, 2019

\section{Gambar 3 dan 4 Proses Latihan Musik dan Pentas di SMAN 1 Jatinangor}

juga melakukan persiapan. Persiapan dilakukan dengan memertimbangkan sarana dan prasarana yang memungkinkan dipersiapkan, serta latihan rutin untuk memastikan pertunjukan dapat berlangsung tanpa kesalahan. Persiapan dan latihan dilakukan hampir setiap minggu, bergantung pada kesepakatan setiap kelompok dengan anggotanya hingga waktu penyelenggaraan acara 31 Mei 2018.

Sasana festival kebudayaan dibuat seperti persegi panjang, menempati Lapangan Futsal Fikom Unpad, di mana satu sisi diisi oleh panggung yang tidak terlalu tinggi menghadap kepada khalayak yang terkonsentrasi di tengah sasana.Sisi-sisi lainnya diisi oleh stand persegi yang berjumlah 25 dengan luas 3 meter x 3 meter. Setiap partisipan 24 dari mahasiswa dan 1 dari Siswa Jatinangor menempati stand tersebut dengan segala ornamen yang mereka gunakan untuk menghias, dapat dilihat pada gambar 5.

Festival secara teoritik dan dalam tataran konseptual merupakan medanruang dan waktu

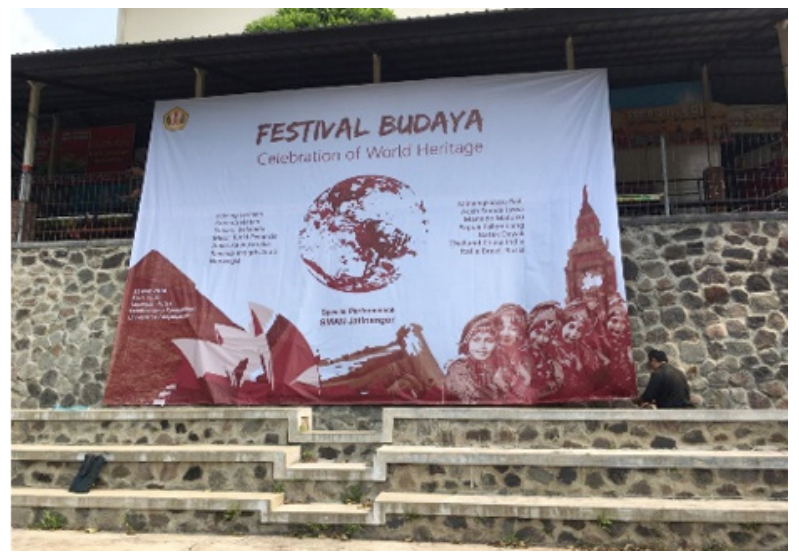

Sumber:Hasil Penelitian, 2019

Gambar 5 Spanduk Festival Budaya

di mana elemen kebudayaan dan diskusi tentang relasi sosial terkonsentrasi. Diskusi ini terkait dengan isu-isu representasi seperti (jenis kelamin, etnis, kelompok usia) yang kemudian akan menggiring pada daya kreativitas (Commission, 2011). Pada penyelenggaraan festival kebudayaan Fikom diskusi dan elemen kebudayaan tersebut terharmonisasi, diskusi juga terjadi walaupun tidak terselenggara dengan formal. Masing-masing peserta bertukar tutur dengan peserta lain dari masingmasing stand untuk membicarakan budaya yang mereka presentasikan. Mereka yang bertanggungjawab terhadap stand mereka akan meladeni dan menjawab pertanyaan para pengunjung yang mendatangi stand mereka. Pertanyaan-pertanyaan yang ada terkait dengan pakaian yang mereka kenakan, latar kebudayaan, ornament yang mereka pilih untuk menghiasi stand mereka, juga tentang keunikan dari etnisitas maupun negara yang menjadi indung dari performativitas yang mereka tampilkan. Festival adalah contoh yang baik tentang cara-cara di mana budaya lokal diekspresikan menggunakan budaya lain. Estetika kosmopolitanisme merupakan metode baru untuk mengekspresikan atau membentuk kembali budaya sendiri dalam terang budaya "liyan" atau orang luar, mengingat kebanyakan penampil sebelumnya asing terhadap detil-detil kebudayaan yang mereka tampilkan sebelum mereka mempelajarinya (Commission, 2011). Di dalam festival, berbagai elemen diadopsi bersama dari berbagai budaya, termasuk budaya global. Dalam pengertian tersebut festival berbeda dari bentuk budaya dari pameran yang 


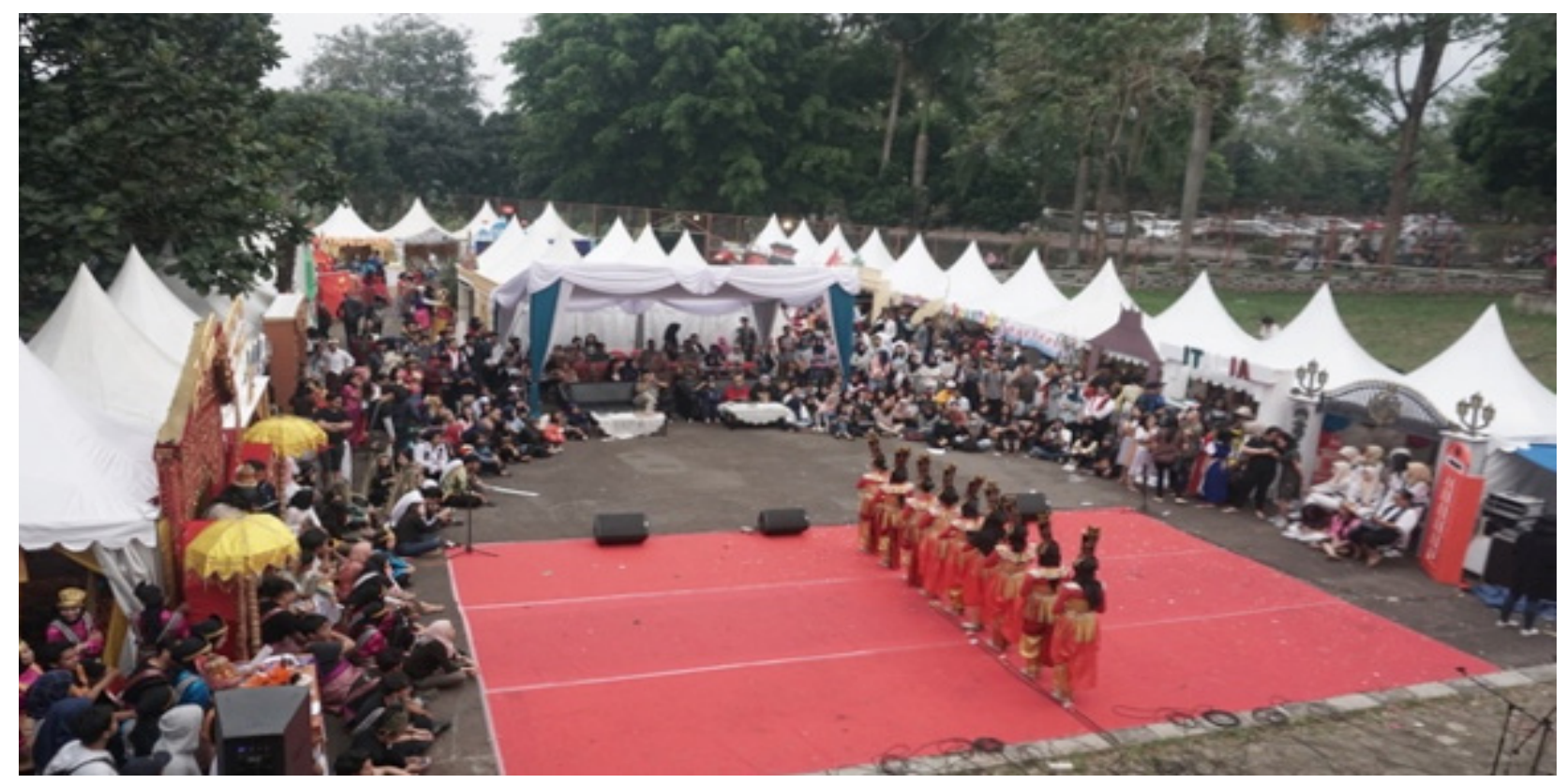

Sumber: Hasil Penelitian, 2019

Gambar 6 Penyelenggaraan Festival Budaya

hanya melibatkan satu aspek, namun juga didasarkan pada hibridasi, penafsiran silang, fertilisasi silang dan saling meminjam satu sama lain (Commission, 2011).

Kecenderungan untuk menciptakan subjeksubjek yang kosmopolitan disetujui oleh para penampil, mayoritas bahkan menyetujui bila festival kebudayaan rutin diselenggarakan di Fikom secara rutin ketika diberi pertanyaan:

"Saya setuju dengan diselenggarakannya festival kebudayaan secara rutin di Fikom, karena dengan kegiatan tersebut mampu mendorong mahasiswa untuk kreatif, dalam hal ini cara mahasiswa mengekspresikan suatu kebudayaan juga pertukaran kebudayaan di dalamnya." T, 20 Tahun.

"Menurut saya festival kebudayaan yang rutin diselenggarakan oleh Fikom sebenarnya dapat dijadikan sebagai sebuah acara yang ikonik. Akan tetapi ada beberapa hal yang harus dikorbankan mulai dari waktu hingga materi." D, 20 Tahun.

"Festival kebudayaan, membuka wawasan tentang budaya dari negara sendiri maupun negara lain. Salah satu acara yang ditunggu penyelenggaraannya." PSM, 19 tahun.

"Festival kebudayaan bagus karena selain memperkenalkan budaya negara sendiri dan negara lain, pada mahasiswa Unpad khususnya Fikom, acara tersebut juga dapat mengasah kreativitas serta kebersamaan dalam grup." WA, 18 tahun.

"Festival kebudayaan berfungsi menambah pengetahuan mengenai budaya berbagai negara. Bagaimana cara berkomunikasi lintas budaya. Juga fungsi lainnya seperti mempersiapkan kita untuk tidak mengalami culture .Maksudnya, setidaknya kita memiliki persiapan untuk berkomunikasi dengan budaya luar." A, 20 tahun.

Hibridasi yang terjalin di dalam kebudayaan yang ditampilkan dapat terlihat dengan jelas, dari busana, ornamen bahkan tarian, dapat dilihat pada gambar 6. Tendensi hibridasi tersebut nampak dari walaupun berupaya menampilkan aspek-aspek kebudayaan yang seolah otentik, namun tanpa malu-malu mereka mengombinasikannyadengan kebudayaan lain dan elemen-elemen modernitas yang sebenarnya juga berasal dari pertukaran dengan budaya lain. Penerjemahan akan upaya menampilkan praktik kebudayaan tidak dilakukan dengan cara mencoba menggali otentisitas namun menerima bahwa praktik-praktik kebudayaan dengan basis etnis untuk lingkup nasional maupun 
yang menggunaan basis negara-negara untuk mewakili dunia internasional pada dasarnya adalah evolusi dan revolusi yang selalu dinamik dan bergerak.

Hal ini sesuai dengan argumen Bhabha (2004) bahwa budaya datang dengan diwakili oleh proses iterasi dan penerjemahan melalui makna tertentu yang dialamatkan "yang lain". Hal yang kontras dengan setiap klaim esensialis bahwa terdapat keaslian atau kemurnian budaya yang melekat, "yang ketika ditulis dalam tanda naturalistik kesadaran simbolik sering menjadi argumen politik untuk hierarki dan kekuasaan budaya yang kuat (Bhabha, 2004).

Salah satu contoh adalah pada bagaimana kelompok yang memperagakan busana India dan Thailand, di mana mereka yang menggunakan kerudung tetap mencoba mengenakan kain Sari dari India begitupun dengan perempuan yang menggunakan kerudung ketika mengenakan busana Thailand: Siwalai dan Borom Bhiman. Walaupun pada dasarnya mereka yang mengenakan kain Sari dan busana khas Thailand tersebut di tanah asalnya jelas tidak menggunakan kerudung, mereka tidak memilih hanya menampilkan anggota kelompok perempuan yang tak berkerudung untuk menampilkan busana-busana tersebut, namun semuanya. Walaupun terlihat remeh, hal tersebut secara ideologis dapat menunjukkan negosiasi di antara nilai agama yang peserta anut dengan aspek-aspek kebudayaan yang mereka ingin presentasikan.

Begitupun dengan kelompok yang mempresentasikan pakaian adat lokal, dapat dilihat pada gambar 7, seperti adat Batak. Pakaian Batak yang dipilih adalah Batak Toba dengan kain ulos sebagai elemen utamanya. Seperti diketahui etnis Batak Toba didominasi pemeluk agama Kristen Protestan, mereka bahkan memiliki kelompok gereja sendiri yang bernama Gereja Suku Batak Toba. Namun terlihat bagaimana perempuan-perempuan yang mengenakan kerudung atau yang memeluk Islam tetap mencoba mengenakan busana pakaian adat Batak Toba tersebut. Dari sana kita dapat menarik simpulan bahwa, festival kebudayaan dapat melatih toleransi bahwa ekspresi-ekspresi kebudayaan seringkali dapat melampaui batas-batas keagamaan selama ia dapat dinegosiasikan dan tidak saling menegasi satu sama lain.

Ketika penampil dari kebudayaan Korea

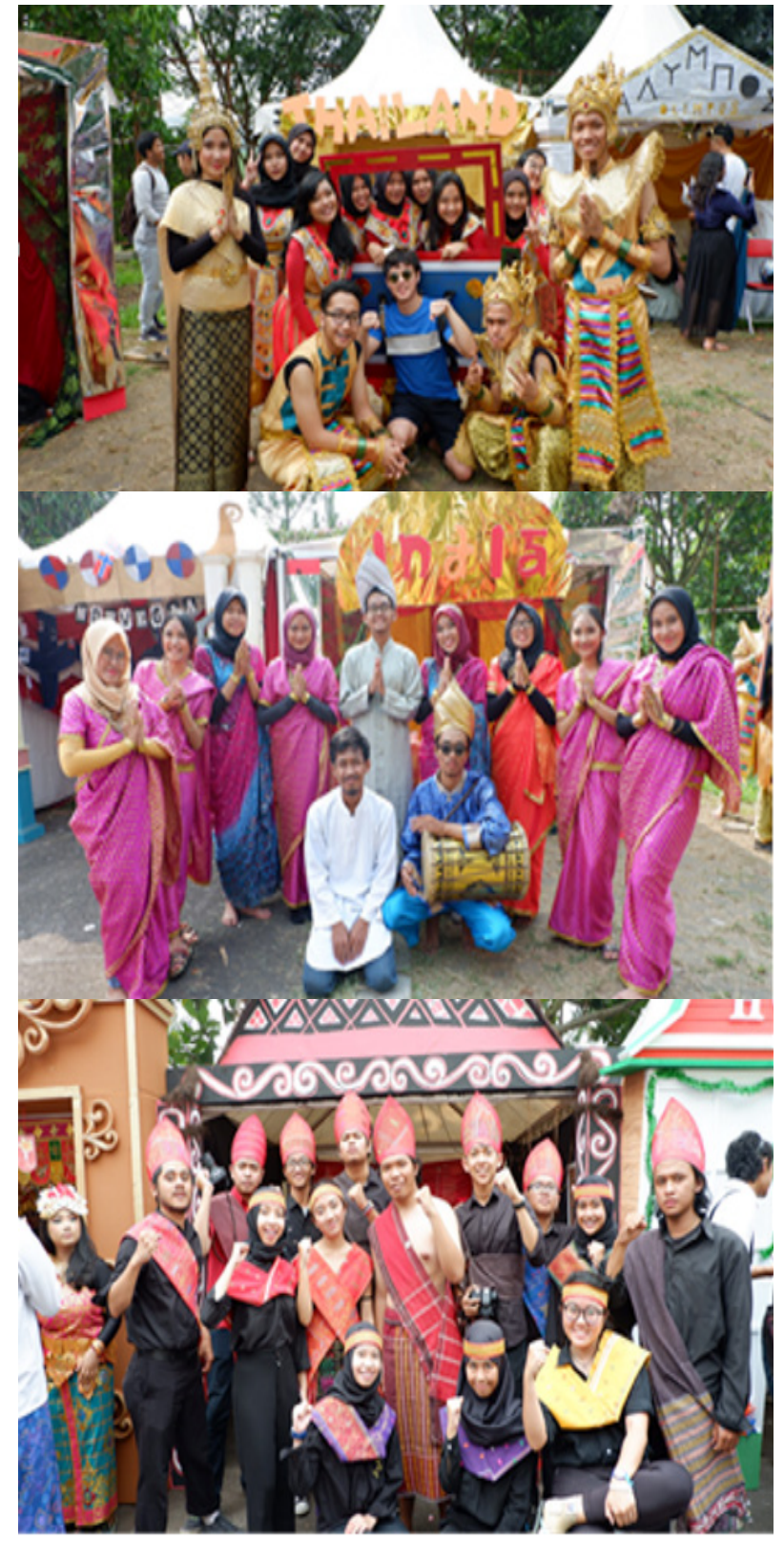

Sumber: Hasil Penelitian, 2019

Gambar 7 Kelompok mahasiswa budaya Thailand, India, dan Batak

menunjukkan diri di stand dan di atas panggung. Peserta tidak hanya berupaya menonjolkan aspek tradisional Korea semata seperti pakaian Han Bok atau hanya menampilkan tarian-tarian kebudayaan tradisional Korea, namun mereka juga mencoba menampilkan produk-produk kebudayaan a la Korean Wave yang merupakan anak kandung dari modernisasi Korea Selatan. Korean Wave atau sering dikenal dengan sebutan Hallyu merupakan budaya populer yang sedang menggejala dan terus tumbuh, tidak hanya di Asia namun juga merambah dunia barat. Kombinasi antara tradisi dengan elemen 
Korean Wave dalam perspektif esensialis, tentu akan dianggap sebagai pencemaran atau bahkan pendangkalan kebudayaan. Namun, apabila ditilik dalam kacamata kosmopolitanisme kebudayaan, hal tersebut dapat menjadi penjelas bahwa tidak bisa tidak kebudayaan akan mengalami modernisasi, dan walaupun ada upaya merawat warisan dari tradisi tidak bisa ditampil hal tersebut akan mengalami pengembangan serta pengadaptasian dari nilainilai baru untuk tetap dapat relevan dalam praktik kehidupan sehari-hari.

Pemahaman akan nilai-nilai toleransi dan kosmopolitanisme disadari oleh para peserta festival kebudayaan, hal tersebut dituturkan oleh mereka:

"Semangat toleransi itu muncul pada saat proses teamwork dan proses pengenalan terhadap budaya-budaya yang ditampilkan. Dengan mengencal ciri khas maupun perbedaan setiap budaya kita dapat mentolerir perbedaan setiap budaya, keanekaragaman.” FT, 20 tahun.

"Dengan menggunakan dan mempelajari berbagai macam budaya, kita menjadi lebih tahu banyak tentang budaya itu, sehingga bisa lebih toleran dengan budaya lain.”TMY, 20 tahun

"Selama festival kebudayaan, toleransi yang ditunjukkan sangat baik. Setiap mahasiswa menjadi sangat penasaran dengan setiap penampilan budaya yang lain, hal yang membuat toleransi yang ditunjukkan juga lebih tinggi."AO, 20 tahun.

"Festival kebudayaan membawa semangat toleransi, karena dapat membuat peserta menghargai budaya-budaya yang berbeda." FNA, 19 tahun.

"Perbedaan di antara kebudayaan menstimulasi saya untuk memahami dahulu sesuatu sebelum menjustifikasi sesuatu, sehingga saya sendiri secara pribadi lebih toleran" MA, 19 tahun.

Pernyataan-pernyataan dari para mahasiswa menjadi representasi bagaimana festival kebudayaan berhasil menjadi eksperimentasi ruang publik, tempat di mana toleransi dilatih untuk bekerja. Ruang publik memang dapat merupa dalam ruang fisik (Adiprasetio \& Saputra, 2017; Adiprasetio \& Saputra, 2018), namun apa yang paling signifikan adalah diskursus kepublikan yang melekat pada dimensi keruangan tertentu (Lefebvre, 2009; Habermas, 1989). Hal ini yang membuat pada dasarnya festival kebudayaan merupakan sarana bagaimana pendidikan multikulturalisme dan pluralisme merupa dalam aktivitas praksis: festival sebagai ajang mengenalkan, mempromosikan sekaligus belajar terkait keberagaman praktik, gestur, produk dan nilai dalam berbagai perwakilan kebudayaan.

Pengenalan atas berbagai hal tersebut yang kemudian menciptakan konsekuensi, bahwa para partisipan tentu saja tidak bisa sembarangan dalam memilih hal-hal apa saja yang ditunjukkan, entah dalam peragaannya atau pamerannya. Para partisipan festival kebudayaan harus dapat mengelaborasi: menunjukkan distingsi sekaligus koneksi di antara aspek luar dari kebudayaan seperti sejarah, seni, peringatan hari libur, folklore, makanan dst, dan aspek dalam dari kebudayaan yaitu kepercayaan, sistem nilai, tindak perlaku, konsep akan waktu, ruang, taboo, mitos dst. Pada festival kebudayaan yang diselenggarakan oleh mahasiswa Fikom ini hal tersebut memang belum sepenuhnya optimal, namun upaya-upaya untuk menunjukkan hal tersebut dapat diamati, seperti para partisipan yang memamerkan kebudayaan Batak menunjukkan bagaimana tentang kebiasaan mengonsumsi hewan babi, lengkap dengan panggangan dan cara memanggangnya. Saat ditanya, mahasiswa juga bisa menjelaskan bagaimana babi sebagai bahan pangan menempati posisi yang khusus, dan menjadi salah satu elemen dari banyak santapan khas Sumatera Utara yang sebagian beretnis Batak dan memeluk agama Kristen.Begitupun dengan partisipan yang memperagakan dan memamerkan kebudayaan negara Belanda, mereka dapat menjawab dengan jelas bagaimana posisi tulip dalam historisitas dan tradisi kebudayaan negara kincir angin tersebut.

Pendalaman pengetahuan dari anggota masing-masing kelompok partisipan adalah modal besar agar pertukaran pengetahuan dapat berlangsung. Selain para tamu, mereka juga saling berkeliling dan sesekali bercengkerama dan bertanya tentang tradisi dari masing-masing asal kebudayaan yang mereka tampilkan: apabila mereka menguasai secara baik tentang materi kebudayaan tersebut, tentu saja diskusi 
dan pembandingan kebudayaan tersebut dapat berjalan secara optimal. Hal yang diharapkan terjadi pada festival kebudayaan yang memiliki tujuan untuk mengampanyekan toleransi atas keberagaman.

\section{SIMPULAN}

Pada dasarnya festival kebudayaan adalah sasana yang tepat untuk mengembangkan visi multikulturalisme dan pluralism, menciptakan ruang ketiga yang dapat menggeser narasinarasi esensialisme kebudayaan (Bhabha, 2004). Riset ini membuktikan bahwa festival dapat menjadi ruang publik di mana secara spesifik dapat ditargetkan untuk menyebarkan nilai-nilai dempkrasi, toleransi, apabila memang partisipannya dilibatkan secara utuh dan berkesinambungan (Habermas, 1989; Kemmis, 2006). Pada konteks riset partisipatif yang melatarbelakangi adanya Festival Budaya: Celebration of World Heritage di Fakultas Ilmu Komunikasi, Universitas Padjadjaran, para partisipannya adalah mahasiswa-mahasiswa, generasi muda yang menjadi tulang punggung dari penegakan semangat toleransi. Keberhasilan penyelenggaraan festival kebudayaan di Fikom menjadi jawaban dan penjelas, bahwa sangat mungkin festival-festival sejenis diselenggarakan di tempat lain dengan tujuan yang sama, dan terutama menyasar generasi muda. Tentu saja diperlukan riset-riset lebih jauh terkait latar, persiapan, penyelenggaraan dan implikasi festival kebudayaan, terutama untuk memperluas peta epistemologi studi kebudayaan khususnya kajian festival yang masih sangat minim di Indonesia.

\section{DAFTAR PUSTAKA}

Adiprasetio, J., \& Saputra, S. J. (2017). Taman alun-alun: produksi ruang (sosial) dan kepublikan. Journal COMMON, 1(2), 118129.

Adiprasetio, J., \& Saputra, S. J. (2018). Taman sempur dan ruang publik: analisis geo-semiotik dan etnografi. Jurnal Komunikasi2, 13(1), 17-40.

Bhabha, H. K. (2004). The location of culture. Routledge.

Commission, E. (2011). European arts festivals strengthening cultural diversity . in European commission. EUROPEAN COMMISSION. https://doi. org/10.2777/48715

Crespi-Vallbona, M., \& Richards, G. (2007). The meaning of cultural festivals. International Journal of Cultural Policy, 13(1), 103-122. https://doi. org/10.1080/10286630701201830

Delgado, M. (2016). Celebrating urban community life: fairs, festivals, parades, and community practice. University of Toronto Press.

Denzin, N. K., \& Lincoln, Y. S. (2005). The sage handbook of qualitative research. New York. Sage Publications.

Fine, G. A. (2012). Tiny publics: idiocultures and the power of the local. Russel Sage Foundation.

Gerintya, S. (Tirto. id. (2018). Periksa data benarkah intoleransi antar-umat beragama meningkat?

Gudykunst, W. ., \& Kim, Y. . (1997). Communicating with strangers (McGrawHill (ed.)).

Habermas, J. (1989). The structural transformation of the public sphere: an inquiry into a category of bourgeois society. Cambridge: MIT Press.

Hadi, D. W. (2017). Analisis faktor-faktor yang mempengaruhi sikap toleransi di Indonesia. 28-29.

Hartoyo, N. M. (2016). Garis-garis besar program pengajaran (gbpp) mata kuliah komunikasi lintas budaya.

Janmaat, J. G., \& Keating, A. (2017). Are today's youth more tolerant? Trends in tolerance among young people in Britain. Ethnicities, 1-22. https://doi. org/10.1177/1468796817723682

Kemmis, S. (2006). Participatory action research and the public sphere. Educational Action Research, 14(4), 459-476. https:// doi.org/10.1080/09650790600975593

Kemmis, S., \& McTaggart, R. (2005). Participatory action research: communicative action and the public sphere. In Handbook of Qualitative Research (pp. 559-603).

King, R. R. (2016). Music, peacebuilding, and interfaith dialogue: Transformative bridges in Muslim-Christian relations. 
International Bulletin of Missionary Research, 40(3), 202-217. https://doi. org/10.1177/2396939316636884

Lee, I. S., Lee, T. J. L., \& Arcodia, C. (2014). The effect of community attachment on cultural festival visitors' satisfaction and future intentions insun Sunny Lee, Timothy Jeonglyeol Lee \& Charles Arcodia Lee, IS , Lee, TJ \& Arcodia, C 2014 ,' The effect of community attachment on cultural fest. Current Issues in Tourism, 17(9), . 800-812.

Lefebvre, H. (2009). The production of space. Oxford: Blackwell.

Liliweri, A. (2007). Dasar-dasar komunikasi antar budaya. Yogyakarta: Pustaka Pelajar.

Lykes, M. B., Hershberg, R. M., \& Brabeck, K. M. (2011). Methodological challenges in participatory action research with undocumented Central American migrants. Journal for Social Action in Counseling and Psychology, 3(2), 22-35.

MacDonald, C. (2012). Understanding participatory action research: A qualitative research methodology option. Canadian Journal of Action Research, 13(2), 34-50.

Moleong, J. L. (2006). Metodologi penelitian kualitatif. Bandung: Remaja Rosdakarya.

Nizah, M. A. M. (2017). The Political tolerance and the youth perceived participation in Malaysia. European Journal of Interdisciplinary Studies, 8(1), 119. https:// doi.org/10.26417/ejis.v8i1.p119-124

Putri, N. E., Hakim, N., \& Yamin, M. (2016). Ecologicall footprint and biocapacity analysis for flooding prevention in South Sumatera. Jurnal Mimbar, 32(1), 58-64.

Rochmanuddin. (2018). [Linimasa] Kasus intoleransi dan kekerasan beragama sepanjang 2018.

Samovar, L., Porter, R. ., \& McDaniel, E. .
(2007). Communication between cultures. Wadsworth.

Setara. (2018). Indeks kota toleran (ikt) tahun 2018.

Shinde, K. A. (2015). Religious tourism and religious tolerance: Insights from pilgrimage sites in India. Tourism Review, 70(3), 179-196. https://doi.org/10.1108/ TR-10-2013-0056

Stoudt, B. G. (2009). The role of language \& discourse in the investigation of privilege: Using participatory action research to discuss theory, develop methodology, \& interrupt power. Urban Review, 41(1), 7-28.

Thomas, R., \& Wood, E. (2003). Eventsbased tourism: a survey of local authority strategies in the uk. Local Governance, Vol 29 (2), 127-136.

UNESCO. (2009). Strengthening the fight against racism and discrimination : unesco 's achievements 2001 world conference against racism, racial 2009 durban review conference. In Review Literature And Arts Of The Americas.

Wood, E., \& Thomas, R. (2006). Research note: measuring cultural values - the case of residents' attitudes to the saltaire festival. TourismEconomics, 12(1), 137-145.https:// doi.org/10.5367/000000006776387187

Wynn, J. R. (2015). usic/City: American Festivals and Placemaking in Austin, Nashville, and Newport. Chicago: University of Chicago Press.

Yeoh, S. G. (2001). Producing locality: Space, houses and public culture in a Hindu festival in Malaysia. Contributions to Indian Sociology, 35(1), 33-64. https://doi. org/10.1177/006996670103500103 